\title{
SUFISM HEALING METHOD FOR DRUGS REHABILITATION: \\ A Case Study in PP. Suryalaya Tasikmalaya, West Java, Indonesia
}

\author{
Ihsan Kamaludin ${ }^{1}$, Maya Najihatul Ula ${ }^{2}$ \\ ${ }^{1}$ UIN Syarief Hidayatullah Jakarta, ${ }^{2}$ Universitas Gajah Mada \\ Correspondence email: ihsankama195@gmail.com
}

\begin{abstract}
Sufism activities cover not only rituals but also pseudomedical treatment. This can be seen from the daily routines of Sufi order (tarekat) of Qadiriah wa Naqsabandiah (TQN) at the Pesantren Suryalaya, Tasikmalaya, West Java. Known as a center of Islamic learning, the pesantren also offers spiritual treatments to cure victims of drug abuse. This study aims to explore this Sufis practices of healing method. Based on an ethnographic study in this locale, the study specifically analyses the method of treatment called inābah. This is a unique technique employed by the Sufis to cure the patients of drug abuse. This study shows that the Sufi masters provides a spiritual and technical guidance in the treatment processes to stimulate drug victims' awareness through a series of spiritual and pseudo-medical processes. In the view of the Sufis, drug abuse can be cured by means of increasing spiritual activities, such as chanting and praying. Moreover, this method also requires embodied practice of repentance by, for example, fasting, bathing and other related ritual processes determined by the Sufi masters. The processes by which the victim take thus include both spiritual and corporal requirements since illness or disease is seen both as a result of spiritual and physical transgressions.
\end{abstract}

Keywords: Inābah, rehabilitation, Sufism healing, Suryalaya

DOI: https://doi.org/10.20414/ujis.v23i2.351

\section{Introduction}

DRUG ABUSE is one of the challenging issues facing by many countries worldwide which require special assistance through 
various strategies. ${ }^{1}$ In Indonesia, drugs abuse rates reach very high levels, a total of 14.244 cases, 18.896 suspected cases, and 17.028 drugs abuse patients in 2018. If it is not immediately resolved, the problem will endanger Indonesian people, especially young generations, in the future because of serious fatalities of the drug misuse. $^{2}$

The increasingly complex problems of drugs abuse encourage various parties to be involved in the process of tackling these social-national problems and to adopt varied curing methods. ${ }^{3}$ Nowadays, there are various model of therapies to treat the victims of drugs abuse (Narcotics, Psychotropic, and other addictive substances), for example psych pharm therapy and pharmacotherapy, which include in pharmacologic therapy and non-pharmacologic therapies, such as psychotherapy with various variations including social therapy, therapeutic communication, acupuncture, and religious therapy. ${ }^{4}$

In addition to the state initiative to deal with drug abuse, several efforts have been made by religious leaders, religious stakeholders, and Islamic institutions to combat drugs abuse. ${ }^{5}$ Islamic boarding school (pesantren) is certainly one active institution in this respect. Pesantren constitute Islamic educational institutions which have different methods of dakwah applied in each school. One method of dakwah is tarekat which is also useful as an alternative way of dealing with drugs abuse. The Suryalaya Islamic Boarding School of Tasikmalaya, West Java, emerges as one leading institutions with a strong tarekat tradition that applies Sufism method to combat and heal drug abuse addicts. ${ }^{6}$

${ }^{1}$ Puji Lestari, "Metode Terapi dan Rehabilitasi Korban Napza di Pondok Pesantren Suryalaya Tasikmalaya," Dimensia 6, no. 1 (March 2012): 1-116.

${ }^{2}$ Ibid.

3 Abdurahman Dudung, "Reaktualisasi Pengamalan Tarekat melalui 'Lembaga Inabah' dalam Penyembuhan Korban Narkoba," Aplikasis, Jurnal Aplikasi Ilmu-Ilmu Agama 4, no. 1 (June 2003): 14-31.

${ }^{4}$ Farhat Naz Rahman, "Spiritual Healing and Sufi Practices," Nova Explore: Publications Nova Journal of Sufism and Spirituality 2, no. 1 (2014): 1-9.

${ }^{5}$ Dudung, "Reaktualisasi Pengamalan Tarekat."

${ }^{6}$ Moh Toriqul Chaer, "Terapi Inabah dan Pecandu," Al-Murobbi 1, no. 1 (December 2014): 60-76. 
The people in the tarekat are called sufis. Sufis themselves are the people who focus their activities on God to establish a close relationship to Him. ${ }^{7}$ They need to cross some congregations to achieved the maqam (the closest position to God). ${ }^{8}$ Tarekat itself, could be loosely defined as groups of people who seek and enter the path of God.

The concepts of the Sufism the practice of 'amaliyah (form of worship) in the tarekat tradition are the sources of the development of religious-based or Islamic-minded therapies, especially for therapeutic processes and techniques. In the world of Sufism and tarekat, there are three stages of spiritual ways, namely tahalli (selfescape from lust and sin), takhalli (self-immersion in good activities), and tajalli (search of divine proximity). ${ }^{9}$ The stages are Islamic psychotherapy techniques and methods. Islamic psychotherapy, referred as an Islamic approach therapy, is a process of treating disorders through the psyche based on religious values (Islam), the Qur'an and Sunna therapy. ${ }^{10}$ According to Hawari, therapeutic Islamic approach is the process of treatment given in accordance with Islamic faiths to improve people awareness of the balance of prayer and dhikr. ${ }^{11}$

The Pesantren Suryalaya is affiliated with Qādiriyya wa Naqshbandiyya sufi order, which was established by Abah Sepuh and then continued by his successor Abah Anom. ${ }^{12}$ Abah Anom initiated the Narcotics and Delinquency Abuse Drug Rehabilitation Institution with the inäbah method (using tarekat 2008).

7 William C. Chittick, Sufism a Beginner Guide (Oxford: A Oneworld Book,

${ }^{8}$ Aboebakar Atjeh, Pengantar Ilmu Tarekat, 3rd ed. (Solo: Ramadhani, 1985).

9 Anangsyah, "Proses Penyadaran Korban Penyalahgunaan Narkotika Melalui Ajaran Agama Islam atau Pendekatan Illahiyah dengan Metode Tasawuf Islam Tarekat Qadariyah Naqsabandiyah di Inabah Pondok Pesantren Suryalaya," in Psikologi Islam, by M. Thoyibi and M. Ngemron (Surakarta: Muhammadiyah University Press, 2006).

${ }^{10}$ Hamdan Mubarakh, Terapi al-Qur'an (Jakarta: Niaga Swadaya, 2006).

11 Dadang Hawari, Al-Qur'an Ilmu Kedokteran Jiwa dan Kesehatan (Jakarta: Dana Bhakti Prima Yasa, 1998).

${ }_{12}$ Sri Mulyati et. al, Tarekat-tarekat Muktabarah di Indonesia (Jakarta: Kencana, 2011). 
activities to rehabilitate the drug abusers). ${ }^{13}$ In addition to serve as a center of Islamic learning, this pesantren, on the basis of Sufi teaching and method, known as inäbah, is an active agent to help community members having social problems with drugs and to restore them to be good members of the community. ${ }^{14}$ This study aims to explore the role of this pesatren in drug abuse treatment. A special analysis will be given to examine the implementation of inābah method in dealing with victims of drug abuse in Suryalaya.

This is an empirical study on this pesantren. The data were gathered through observation and interview. To gain direct observation and firsthand data, the authors stayed in the pesantren for one month, observing the inäbah and interviewing the kiai, who cure the patients, and those who were being treated as the victim of drug abuse. The authors also interviewed the head program of the drug healing and uses archives and documents regarding the program.

The discussion in this paper is divided into some parts. The first part is the institutionalization of Sufi order (tarekat) in the Pesantren Suryalaya. The next part explores the inābah method as the core procedure of drug abuse healing. The last part of the analysis discusses the effectiveness of this method.

\section{Tarekat Qādiriyya Naqshbandiyya and the Pesantren Suryalaya}

Tarekat grew rapidly in the 19th century and played an important role in the Islamization of Nusantara archipelago. ${ }^{15}$ Tarekat Qādiriyya Naqshbandiyya (TQN) was also present as a combination of two prominent congregations namely the Qãdiriyya Order and the Naqshabandiyyah Congregation which were practiced in the daily lives of its members. TQN was first

${ }^{13}$ Khairunnas Rajab, "Methodology of Islamic Psychotherapy in Islamic Boarding School Suryalaya Tasik Malaya," IJIMS, Indonesian Journal of Islam and Muslim Societies 4, no. 2 (December 2014): 257-289.

${ }^{14}$ Dudung, "Reaktualisasi Pengamalan Tarekat."

15 Sean Foley, "The Naqshbandiyya-Khalidiyya, Islamic Sainthood, and Religion in Modern Times," Journal of World History 19, no. 4 (December 2008): 521-545. 
taught by Sheikh Ahmad Khatib Sambas who was an expert in the field of Sufism and Islamic teachers in Mecca. ${ }^{16}$

Merging these two teaching approaches is considered complementary in the process of individual approach to the God. The widespread of TQN on the island of Java can be seen from the establishment of several Islamic boarding schools including the Suryalaya Islamic boarding school (Pesantren) in Tasikmalaya founded by Syaikh Abdullah bin Nur Muhammad (often referred to as Abah Sepuh) in 1905. ${ }^{17}$ This pesantren is one of the bases for the spread of TQN, especially in West Java and during the leadership of KH. Ahmad Shohibulwafa Tajul Arifin (known as Abah Anom). The existence of the Serba Bakti Suryalaya Foundation is increasingly popular especially after the establishment of the inābah institution as a rehabilitation institution for drug addicts. ${ }^{18}$

The teaching approach of TQN according to residents of rehabilitation is a way of channeling focus and changing old habits in their environment into new religious habits. Social solidarity and religious activities carried out by all residents are the main keys of community development to recover from drug dependence. ${ }^{19}$

The Suryalaya Islamic Boarding School was established on 7 Rajab $1323 \mathrm{H}$ or September $5^{\text {th }}, 1905$ by Shaikh Abdullah Mubarok bin H. Nur Muhammad with the initial capital of a mosque located in the village of Godebag, Tanjung Kerta, Pagerageung, Tasikmalaya. ${ }^{20}$ Geographically, the Suryalaya Islamic Boarding School is in the highland, about $30 \mathrm{~km}$ from the district capital and

${ }_{16}$ Karel A. Steenbrink, “Department of History, National University of Singapore," Journal of Southeast Asian Studies 25, no. 2 (September 1995): 421-423.

${ }_{17}$ Mulyati et. al, Tarekat-tarekat Muktabarah.

${ }^{18} \mathrm{https}$ ://www.suryalaya.org accessed on December 12, 2018 AT 08.23 AM

${ }^{19}$ Interview with Rendi and lexy, March 29, 2017 at 10.17 AM

20 Marhaban, "The Implication of Abah Anom'sDhikr OnReligious in Modern Life," IOSR Journal of Humanities and Social Science (IOSR-JHSS) 22, no. 3 (March 2017): 73-81. 
about $180 \mathrm{~km}$ to the east from Bandung, the capital of West Java Province, the Citanduy River. ${ }^{21}$

The name of the pesantren is taken from the Sundanese term; Surya, which means the Sun, and Laya, which means the place to rise. Thus, Suryalaya literally means the sunrise which implicitly symbolizes the rising sun by Shaykh Abdullah Mubarok bin $\mathrm{H}$. Nur Muhammad so that all servants Allah who came to the Suryalaya Islamic Boarding School in his heart could be illuminated with the light of faith, as God illuminates this earth with endless sunlight. ${ }^{22}$

\section{Inābah Therapy}

The name inābah was given directly by KH. Shahibul Wafa Tajul Arifin (Abah Anom) by referring to the Qur'an which means "return to the path of Allah (al-rujū' ilā Allāh) with obedience to Him". Thus, "inābah is returning to Allah by carrying out obedience to Him and away from disobedience to Him. The meaning of inäbah is similar to repentance, except that inäbah is subtler than repentance because it contains a feeling of dependence on God and repatriates the matter to Him." 23

In the concept of Sufism, there are several maqāmāt (stages) that must be passed through by people who want to rid themselves of various sins and try to get closer to God. ${ }^{24}$ The first is repentance, which is an effort to cleanse oneself and soul from various minor sins and great sins. In regard to repentance, there are three stages, namely: intiqālah is the first phase in the form of leaving $\sin ($ takhalli $)$. Inäbah is a phase where in addition to leaving sin and returning to the path of Allah by redeeming through various worship activities (tahalli ). Repentance regretting the sins one has committed and trying not to do them again and replaced

${ }^{21}$ Alhamuddin, “Merawat Jiwa Menjaga Tradisi: Dzikir dan Amal Tarekat Qadiriyah Naqsabandiyah dalam Rehabilitasi Korban NAPZA sebagai Terapis Ala Islam Nusantara," Sosial Budaya: Media Komunikasi Ilmu-Ilmu Sosial Budaya 12, no. 1 (June 2015).

${ }^{22}$ Chaer, "Terapi Inabah dan Pecandu."

${ }^{23}$ Ibid.

${ }^{24}$ Rajab, "Methodology of Islamic Psychotherapy." 
by carrying out various good deeds (worship). ${ }^{25}$ The last phase begin when the people try to learn and implement Islamic values and rules to strengthening their bond with Allah (tajallī).

In summary, the phase of restoration of consciousness and clearance (of all sins), are provided with the services held by inābah institution in the following order: (1) 40 First Day Services (Thakhalli). The participants cannot contact with anybody else so that they can focus on their spiritual activism (2) the next 40 Day (Tahalli) Coaching Process, (3) Services for the Third 40 Day is Development Phase, stabilizing and strengthening praying so they could reach advanced development in worship (Tajalli). All religious activities are believed to be able to restore the spiritual awareness of members who deviate from the rules of religion and accustom them to carrying out various Islamic worship activities. Community members are expected to be good ones and help society in their area to get to know Islam deeper. ${ }^{26}$

The community members participating in all activities in inābah institution are people who are willing to take part in the entire program or are included by their family members. The family only needs to provide several pieces of basic clothing and equipment such as toiletries to family members to be used in daily activities. New community members are not allowed to contact their family members in some time so that they are able to focus on adapting to the various activities. ${ }^{27}$

The are several components of this healing method. ${ }^{28}$ These include teacher-student relationship and procedure of treatment. ${ }^{29}$ The first important element is murshid or shaykh. He is leaders or professors in a congregation and determinants of all proximity activities or Sufism activities of their students. They are professionals (therapists) who carry out verbal emphatic communication to understand their patients mental condition and the extent to which they have lost their way, following by an

\footnotetext{
${ }^{25}$ Alhamuddin, "Merawat Jiwa Menjaga Tradisi."

${ }^{26}$ http://www.inabah.com/p/falsafah.html accessed on April 102019 at 08.12

${ }^{27}$ Interview with Dudin, March 29, 2017 at 10.30 AM

${ }^{28}$ Chaer, "Terapi Inabah dan Pecandu."

29 Alhamuddin, "Merawat Jiwa Menjaga Tradisi."
} PM 
explanation of Islamic life principles in understanding Sufism and giving lessons (talqin).

The second is the coaches are namely the operational implementers who foster daily living in inäbah youth dormitory who consistently and continuously guide the patients for 24 hours. The third is curriculum in the form of various worship activities that must be carried out by each patient during the healing period, either in the form of obligatory worship, circumcision, bathing repentance, dhikr (some invocation which need to repeat more than 300 times once by the people after salät or pray), khataman (pray in special event to finish read Koran and dzikir), manakiban (special event that held to gather and listen some speech by Murshid or Islamic priest), and others.

Forth, Infrastructure facilities are highly imperative as the supporting component to situate all patients, so that it can be easier to forget about various mental problems or forget about various bad habits that damage their soul. These facilities and infrastructures include accommodation, housing, mosques, the availability of water, and sports facilities. fiPatients who will undergo therapy must follow the terms and conditions such as practicing TQN.

\section{Treatments for the Drugs Addicts}

The concept of the care to the victims of drugs abuse is to restore their behavior that always opposes God's will or is immoral, to behavior that is in accordance with God's will. ${ }^{30}$ Patients, who have just entered the rehabilitation in inābah institution, undergo convulsions (sakau) since they do not consume the drugs. This inābah method is indeed different compared to conventional methods that provide drugs with a lower drug composition so that patients who are sick can subside. The drug given is usually in the form of methadone. ${ }^{31}$

${ }^{30}$ Chaer, "Terapi Inabah dan Pecandu."

${ }^{31}$ Oktavianus in Gede Indra Surya Lasmawan and Tience Debora Valentina, "Kualitas Hidup Mantan Pecandu Narkoba yang Sedang Menjalani Terapi Metadon," Jurnal Psikologi Udayana 2, no. 2 (2015). 
Usually, the coaches and community members help the patients by reading the Qur'anic verses or pray and guiding the patient to remember God. The morning bathing procession is believed by the inābah institution as an activity that is able to reduce the intensity of sakau because the body is given positive energy and continued with honing the focus to worship God. ${ }^{32}$

The healing techniques used in the TQN Suryalaya include several steps. ${ }^{33}$ The first step is talqin. It is a reading of prayer by a prospective member as a first step before officially becoming one of the members of the community. Its aim is to state the ability to carry out every activity continuously in daily life. The Talqin procession is a proof that binds the members to develop morality so that they continue to carry out various tarekat practices until they are declared cured of drug dependence and usually show an attitude that is always close to God. Talqin rituals can be done individually or in groups but do not eliminate the essence of the statement obedient to the rules they are ready to carry out.

The second step is bathing of repentance. This refers to a practice usually carried out by sufis and tarekat experts with the intention of repenting or removing various sins from all members of the body, from the tip of the hair to the tips of the feet. It is very effective to increase self-awareness (self-consciousness) and healing from various diseases that are in accordance with the understanding and interpretation of the word of God in Qs. alNisā': 43 and Qs. al-Anfāl: $11 .^{34}$ Bath repentance has therapeutic benefits for diseases or biological (physical) disorders that are psychosomative. It is seen as a hydro therapy or treatment by using water as ingredients. According to Simon Baruch (18401921), an American doctor, that water does have a sedative power if the water temperature is the same as the skin's temperature, and has the stimulating power if the water temperature is not the same as the skin's temperature. Whereas according to Ewalt, patients who experience alcohol delirium and who show anxiety, agitation, overactivity, acute anxiety, and tumors due to drug poisoning

\footnotetext{
${ }^{32}$ Interview with udin, March 29, 2017 at 10.30 AM

${ }^{33}$ Chaer, "Terapi Inabah dan Pecandu."

${ }^{34}$ Ibid.
} 
show a good response to hydro therapy. In inābah institution, it is used to be doing in the early hours of the morning or before the evening pray. With the practices, the community is able to focus and be purified from various heart diseases such as being lazy and disobedient to the details of activities that they must carry out and can get used to discipline to clean themselves as early as possible to be ready to worship. ${ }^{35}$

The third is prayer of mahdhah (ritual) that has been standardized in Islam and a highly preferred method of selfawareness. Every patient is obliged to carry out compulsory pray. Its application as one of the methods of tazkiyah nafs is based on the idea that pray has wisdom that can affect one's personality not to act viciously (adultery, gambling, drinking liquor and the like) and all kinds of conductive and anarchic actions. Pray will lead people who carry it out to realize the majesty of God, and at the same time raise awareness of their own weaknesses, so that at this time someone will become aware of his position and God. In addition to psychological benefits as therapeutic, pray also has somatic or psychosomative benefits since mechanically the movements in pray have aspects of sports and acupuncture that are therapeutic. Every movement or stroke according to a review of reflection and acupuncture is very beneficial for physical health which will stimulate nerve nodes in the limbs. While the reading that is meditation and suggestion is beneficial for one's mental, spiritual, and spiritual health.

Pray is performed by community members on average amount of 114 rakaat after bathing repentance until the evening. This is indeed felt tiring at first but after getting used to it, the people will get peaceful life $\mathrm{e}^{36}$

Dhikr is the principal practice in TQN which has enormous benefits in the effort to clean the soul. The words Lā Iläha illallāh is spoken loudly accompanied by movements of body referring to the guidance of murshid. Also, it is read in the heart (khafi) which

35 Ina Noor Khiyar Nafisa, “Efektivitas Metode Inabah terhadap SelfAwareness pada Pencandu Alkohol (Studi Eksperimen di Pondok Inabah Pesantren Suryalaya" (Undergraduate Thesis, Universitas Islam Negeri Sulthan Syarif Kasim Riau, 2010).

${ }^{36}$ Interview with Agus, March 29, 2017 at 10.30 AM 
each individual must continue to practice in every single condition in the daily basis. Dhikr is a manifestation of one's commitment to always mention and remember Allah, instilling an awareness that there is no god but Allah. In the hadith it is said about the benefits of $d h i k r$, "Indeed for everything there is a cleaning tool, and in fact the cleanser of the heart (soul) is dhikr to Allah. And there is nothing more able to save from the punishment of Allah than dhikrulläh (H.R.Baihaqi)." The practice of loud dhikr is usually carried out between two pray or after the whole series of pray are finished.

The next step is tahajud or night prayer as one method of cleansing the soul. The implementation of the Tahajud is emphasized to give more self-cleaning effects and various psychological benefits. The habit of praying at night has a variety of purposes such as, one third of the night is believed to be the right time to pray to Allah, the patients are instructed to pray and ask for fluency in their rehabilitation process. The whispering of the mid-night pray is also expected to be a trigger for community members to always remember and carry out the series of services starting from the time they wake up.

The next procedure is fasting, which constitutes another important practice of inäbah. Fasting has an extremely important value in cleansing the soul, since holding back from eating, drinking, and having sex as main acts of fasting improve the quality of the soul and weaken the power of animal lust and human primitive potential. Fasting, both the compulsory and the circumcision, can suppress the low nature of human beings and nourish the body and soul. The schedules of fasting are on Monday and Thursday in each week and three days in the mid of the month of Hijri (Islamic calendar). In addition, the habit of fasting is able to make community members do rethinking about every activity they will do because they are afraid to damage their fasting rewards. Besides fasting has various other psychological benefit, it is also very useful for body health or psychosomatic, such as the creation of health and acidic balance of gastric base, high blood pressure, and a control of cholesterol.

Activities usually begin at 2:00 a.a. when community members are required to wake up for repentance bathing guided by the leader of inābah institution. 
After the procession is complete, they are also required to perform a number of sunnah pray totaling 33 rakaat before the minimum 165 times of dzikr or until 4.00 a.m. When the pray calls echoes, they pray again before the main dawn pray and then continued with dzkir and khataman (reading a few verses and prayers). Religious activities in the form of pray and dzikr which start from the early hours until completion at around 9.30 p.m. are carried out continuously every day so that the members are accustomed to worship and are expected to always remember God in every activity. The remembrance and charity of the TQN are also believed to be the right method of rehabilitation for drug addicts and mental therapy because the system of healing based on Nusantara Islam is in accordance with the culture of Indonesian society. ${ }^{37}$

\section{The effectiveness and evaluation of Inābah Therapy}

The evaluation of inābah treatment is an effort to determine the achievement of the objectives of the prescribed healing process and the coaching process. ${ }^{38}$ The basic principle that must always be considered and held in the framework of assessing the process of formation in inäbah is the principle of comprehensiveness, both in terms of understanding the material that has been given (cognitive), aspects of appreciation (affective), and practice (psychomotor), and behaviors related to motivation or drive (cognitive). ${ }^{39}$ The aspects or psychological domain are very close and even impossible to be released from evaluation of inābah. ${ }^{40}$

Inābah is one of the spiritual approaches used to heal drugs addicts. It is believed that drug addicts are involved in such a state due to their lack of inner peace; loss of heart and faith, low level of taqwa. ${ }^{41}$ Tasawwouf has proven to be very effective in educating the human soul, offering peacefulness to the mind and filling up the sense of emptiness inside one's heart. Many Muslim scholars acknowledge that understanding tașawwuf is one of the important

${ }^{37}$ Interview with Dudin, March 29, 2017 at 10.30 AM

38 Dara Aisyah et. al, "Drug Addict Treatment and Rehabilitation Programme at Pondok Inabah, Kuala Terengganu, Terengganu, Malaysia (19982011)," British Journal of Social Sciences 1, no. 5 (February 2013): 37-46.

${ }^{39}$ Margaret Wills, "Connection, Action, and Hope: An Invitation to Reclaim the 'Spiritual' in Health Care," Journal of Religion and Health 46, no. 3 (September 2007): 423-436.

${ }^{40}$ Chaer, "Terapi Inabah dan Pecandu."

${ }^{41}$ Aisyah et. al, "Drug Addict Treatment." 
aspects in the teachings of Islam. Tasawwuf has given its spirit in the whole structure of Islam, both socially and intellectually. ${ }^{42}$ This study also shows that the period of therapy in inäbah have a positive relevance with a decrease in symptoms of physical complaints and somatization. It is consistent with Ina Noor's research stating that the inäbah method is quite effective and efficient in the process of self-awareness of alcoholics with a success rate of $80 \%-92 \%$. The predominant reason of this result is the practices of talqin and dhikr which provide a number of prominent psychological aspects, namely problem solving, catharsis (release of hidden emotions), eliminating anxiety, improving self control, and giving insight. ${ }^{43}$

In fact, many drugs addicts during the rehabilitation and after rehabilitation period are not strong in facing various life challenges and eventually there is a feeling of longing and a strong desire (suggest) to return to using drugs or relapse. In addition, the temptation of the surrounding environment or peers who are mostly addicts also cause former addicts to potentially use drugs again. It shows that during the rehabilitation and after rehabilitation phase, drugs addicts find it difficult to defend themselves from re-use the drugs. ${ }^{44}$ Recurrence or relapse shows that former drugs users who have recovered consume drugs regularly again. The recurrence process is caused by a loose behavior again, in this case the users feel satisfied by returning to using drugs when the situation or social habits, without feeling that he has a serious problem. This behavior in psychology is popularly called self-control. ${ }^{45}$

Although the principle of assessment within the inäbah has been tried as tightly as possible, some of them have returned to inābah institution again.

42 Ibid.

${ }^{43}$ Nafisa, "Efektivitas Metode Inabah."

${ }^{44}$ Ilmi Hidayati, "Metode Dakwah dalam Menguatkan Resiliensi Korban Penyalahgunaan Narkotika, Psikotropika, dan Zat Adiktif lainnya (Napza)," Jurnal Ilmu Dakwah 36, no. 1 (June 2016).

45 Agus Sofyandi Kahfi and Dewi Rosiana, "Metode Dakwah dalam Menguatkan Resiliensi Korban Penyalahgunaan Narkotika, Psikotropika, dan Zat Adiktif lainnya (Napza)," Mimbar 29, no. 1 (June 2013): 77-84. 
This mainly is because when they return to their old environment, friends who are still addicts invite them to use drugs again. ${ }^{46}$

Another factor that plays an important role is self-awareness. The awareness of patients who are undergoing inābah therapy apart from the effectiveness of the therapy itself is back to the motivation of the individual concerned, because this relates to what he thinks and feels (cognitive processes and affective) and what he does (psychomotor). Will he remain in his original state before he is given therapy or will he change after he is given therapy. ${ }^{47}$ Individuals with a higher level of religiosity tend to have a higher level of commitment. Thus, religiosity programs function as positive resources. In the programs where the patients as a whole view religion as an important resource to improve recovery, a person's level of personal religiosity can be an effective resource for increasing retention. ${ }^{48}$

Hence, some patients who will leave the institution decided to study at the Suryalaya boarding school and some were even believed to be assistant teachers there. This happened because the former patient felt that his life was enlightened by TQN so that he wanted to focus on worshiping God and also be able to be useful to the community. ${ }^{49}$

\section{The Ultimate Goal of Inābah Therapy}

The rehabilitation program for drugs addicts through religious and spiritual approaches contributes some light to solving the drugs problem. Various religions have their own ways to do such treatments, especially in Islam, the treatment is based on the Qur'an and Hadith. This is because; Islamic rehabilitation therapy aims to shape a perfect (kāmil) human form that is well balanced in terms of physical needs, intellectual, and sense of humanity. ${ }^{50}$

Inābah therapy brought by Abah Anom with Tarekat Qādiriyya Naqsyabandiyah (TQN) is a psychic healing method - a treatment

${ }^{46}$ Interview with Agus, March 28, 2017 at 10.30 AM

${ }^{47}$ Nafisa, "Efektivitas Metode Inabah."

${ }^{48}$ Joseph J. Shields et. al, "Religion and Substance Abuse Treatment: Individual and Program Effects," Journal for the Scientific Study of Religion 46, no. 3 (September 2007): 355-371.

${ }^{49}$ Interview with Agus, March 28, 2017 at 10.30 AM

${ }^{50}$ Aisyah et. al, "Drug Addict Treatment." 
and cure for physical, mental, or psychological, spiritual or spiritual illnesses with religious methods and also uses Sufism theory as a method healing. ${ }^{51}$ This method covers many aspects of life, both related to understanding and action, where Sufism, especially the tarekat, is very influential in the process of returning to purity of heart and peace of life for those who practice it. ${ }^{52}$

In general, the Sufism healing method is very effective and useful in increasing concentration, reducing stress, releasing chaotic anxiety and thoughts, increasing awareness and insight, restoring the balance of magnetic resonance and self-defense. ${ }^{53}$ The final result is a victim will be able to raise themselves up, arouse the qualities of the human soul that have a positive impact on their lives such as love and affection, patience, tolerance, forgiveness, satisfaction, a sense of responsibility, a sense of peace and harmony that brings happiness to both self and other people around him. ${ }^{54}$ Equally important is teaching to act against lust (mujāhadah) with practice (riyādah) and diligently in selfintrospection (muhāsabah), broad-minded and moderate life that is not trapped by lust. ${ }^{55}$ So, after the patients left PP Suryalaya, the persons can be proportional and wise in the world, have a calm and equanimous spirit, live more dynamically, be optimistic and more faithful and not easily tempted to do bad things again. ${ }^{56}$

Community members also assume that there is a miracle that will be obtained after the therapy is complete. This according to them happens in their social life or their friends. They think that God shows love when they try to improve their therapy practice. Getting a better quality of life or becoming a person who is given a job is easily a common and trusted example they will soon get when they leave inäbah institution. ${ }^{57}$

${ }^{51}$ Siti Nur Aini, "Konsep Sufi Healing Menurut M. Amin Syukur dalam Perspektif Bimbingan Konseling Islam" (Undergraduate Thesis, Universitas Islam Negeri Walisongo Semarang, 2015).

52 Marhaban, "The Implication of Abah Anom's."

${ }^{53}$ Aini, "Konsep Sufi Healing."

${ }^{54}$ Derek P Apanovitch, "Religion and Rehabilitation: The Requisition of God by the Stat," Duke Law Journal 47, no. 4 (February 1998): 785-852.

${ }^{55}$ Rahman, "Spiritual Healing."

${ }^{56}$ Marhaban, "The Implication of Abah Anom's."

${ }^{57}$ Interview with Andi, March 28, 2017 at 10.30 AM 


\section{Conclusion}

The actualization of religion in life by creating effective and efficient methods especially in providing alternative therapies is key to the inābah method. Inābah shows the application of religious teachings which are actually not new in Islam, namely the teachings of the Prophet Muhammad. The focus of inābah therapy lies in giving treatment to the drugs addicts which contribute to their rehabilitation by touching his feelings with the teachings of Islam through the practices of TQN. The therapy start from main activities; bathing repentance, pray, dhikr, and fasting, and other supporting means such as reading the Qur'an, recitating the Qur'an, and learn figh, tawhìd, morals, and Sufism. These practices are carried out simultaneously and continuously until the awareness of the patients grows along with the frequency of implementation inäbah therapy. The result of therapy is that the patients can return to the right path, increase faith and piety, get deeper into religion, and be able to return to the social environment with a stronghold of faith to stay away from things that are prohibited by religion.

\section{References}

Aini, Siti Nur. "Konsep Sufi Healing Menurut M. Amin Syukur dalam Perspektif Bimbingan Konseling Islam." Undergraduate Thesis, Universitas Islam Negeri Walisongo Semarang, 2015.

Aisyah et. al, Dara. "Drug Addict Treatment and Rehabilitation Programme at Pondok Inabah, Kuala Terengganu, Terengganu, Malaysia (1998-2011)." British Journal of Social Sciences 1, no. 5 (February 2013): 37-46.

Alhamuddin. "Merawat Jiwa Menjaga Tradisi: Dzikir dan Amal

Tarekat Qadiriyah Naqsabandiyah dalam Rehabilitasi Korban NAPZA sebagai Terapis Ala Islam Nusantara." Sosial Budaya: Media Komunikasi Ilmu-Ilmu Sosial Budaya 12, no. 1 (June 2015). Anangsyah. "Proses Penyadaran Korban Penyalahgunaan

Narkotika Melalui Ajaran Agama Islam atau Pendekatan Illahiyah dengan Metode Tasawuf Islam Tarekat Qadariyah Naqsabandiyah di Inabah Pondok Pesantren Suryalaya." In 
Psikologi Islam, by M. Thoyibi and M. Ngemron. Surakarta: Muhammadiyah University Press, 2006.

Apanovitch, Derek P. "Religion and Rehabilitation: The

Requisition of God by the Stat." Duke Law Journal 47, no. 4 (February 1998): 785-852.

Atjeh, Aboebakar. Pengantar Ilmu Tarekat. 3rd ed. Solo: Ramadhani, 1985.

Chaer, Moh Toriqul. "Terapi Inabah dan Pecandu." Al-Murobbi 1, no. 1 (December 2014): 60-76.

Chittick, William C. Sufism a Beginner Guide. Oxford: A Oneworld Book, 2008.

Dudung, Abdurahman. "Reaktualisasi Pengamalan Tarekat melalui 'Lembaga Inabah' dalam Penyembuhan Korban Narkoba." Aplikasis, Jurnal Aplikasi Ilmu-Ilmu Agama 4, no. 1 (June 2003): 14-31.

Foley, Sean. "The Naqshbandiyya-Khalidiyya, Islamic Sainthood, and Religion in Modern Times." Journal of World History 19, no. 4 (December 2008): 521-545.

Hamdan Mubarakh. Terapi al-Qur'an. Jakarta: Niaga Swadaya, 2006.

Hawari, Dadang. Al-Qur'an Ilmu Kedokteran Jiwa dan Kesehatan. Jakarta: Dana Bhakti Prima Yasa, 1998.

Hidayati, Ilmi. "Metode Dakwah dalam Menguatkan Resiliensi Korban Penyalahgunaan Narkotika, Psikotropika, dan Zat Adiktif lainnya (Napza)." Jurnal Ilmu Dakwah 36, no. 1 (June 2016).

Kahfi, Agus Sofyandi, and Dewi Rosiana. "Metode Dakwah dalam Menguatkan Resiliensi Korban Penyalahgunaan Narkotika, Psikotropika, dan Zat Adiktif lainnya (Napza)." Mimbar 29, no. 1 (June 2013): 77-84.

Lasmawan, Gede Indra Surya, and Tience Debora Valentina. "Kualitas Hidup Mantan Pecandu Narkoba yang Sedang Menjalani Terapi Metadon." Jurnal Psikologi Udayana 2, no. 2 (2015).

Lestari, Puji. "Metode Terapi dan Rehabilitasi Korban Napza di Pondok Pesantren Suryalaya Tasikmalaya." Dimensia 6, no. 1 (March 2012): 1-116. 
Marhaban. "The Implication of Abah Anom'sDhikr OnReligious in Modern Life." IOSR Journal of Humanities and Social Science (IOSR-JHSS) 22, no. 3 (March 2017): 73-81.

Mulyati et. al, Sri. Tarekat-tarekat Muktabarah di Indonesia. Jakarta: Kencana, 2011.

Nafisa, Ina Noor Khiyar. “Efektivitas Metode Inabah terhadap Self-Awareness pada Pencandu Alkohol (Studi Eksperimen di Pondok Inabah Pesantren Suryalaya." Undergraduate Thesis, Universitas Islam Negeri Sulthan Syarif Kasim Riau, 2010.

Rahman, Farhat Naz. "Spiritual Healing and Sufi Practices." Nova Explore: Publications Nova Journal of Sufism and Spirituality 2, no. 1 (2014): 1-9.

Rajab, Khairunnas. "Methodology of Islamic Psychotherapy in Islamic Boarding School Suryalaya Tasik Malaya." IJIMS, Indonesian Journal of Islam and Muslim Societies 4, no. 2 (December 2014): 257-289.

Shields et. al, Joseph J. "Religion and Substance Abuse Treatment: Individual and Program Effects." Journal for the Scientific Study of Religion 46, no. 3 (September 2007): 355-371.

Steenbrink, Karel A. "Department of History, National University of Singapore." Journal of Southeast Asian Studies 25, no. 2 (September 1995): 421-423.

Wills, Margaret. "Connection, Action, and Hope: An Invitation to Reclaim the 'Spiritual' in Health Care." Journal of Religion and Health 46, no. 3 (September 2007): 423-436.

https://www BNN.go.id accessed on April 152019 at 08.12 PM https://www.suryalaya.org accessed on December 12, 2018 at 08.23 $\mathrm{AM}$

http://www.inabah.com/p/falsafah.html accessed on April 102019 at 08.12 PM 